\title{
Isotherms and isosteric heat of sorption of two varieties of Peruvian quinoa
}

\author{
Augusto Pumacahua-Ramos ${ }^{1,2, *}$; José Antonio Gomez Vieira²; Javier Telis- \\ Romero $^{2}$; Harvey Alexander Villa-Vélez ${ }^{3}$; Jose Francisco Lopes Filho ${ }^{2}$ \\ ${ }^{1}$ Professional School of Engineering in Food Industry, Universidad Peruana Unión - UPeU, Carretera Arequipa, Km 06, \\ Juliaca, Puno, Peru. \\ 2 Department of Food Engineering, Instituto de Biociências, Letras e Ciências Exatas - IBILCE, Universidade Estadual \\ Paulista - UNESP, Rua, Cristóvão Colombo, 2265. ZIP 15054-000 São José do Rio Preto, SP-Brazil. \\ ${ }^{3}$ Coordination of Chemical Engineering, Center of Exact Sciences and Technologies, Universidade Federal do Maranhão, \\ Av. dos Portugueses 1966, Zip: 65085-580, São Luís-MA, Brazil.
}

Received May 31, 2016. Accepted November 07, 2016.

\begin{abstract}
The isosteric heats of sorption of two varieties of quinoa (Chenopodium quinoa Willd.) grain were determined by the static gravimetric method at four temperatures $\left(40,50,60\right.$ and $70{ }^{\circ} \mathrm{C}$ ) and in relative humidity environments provided by six saturated salt solutions. Six mathematical equations were used to model the experimental data: GAB, Oswin, Henderson, Peleg, Smith and Halsey. The isosteric heat of sorption was determined using the parameters of the GAB model. All the equations were shown to be appropriate by the coefficients of determination $\left(\mathrm{R}^{2}\right)$ and the mean absolute error (MA\%E). The influence of temperature was observed because the adsorption of water by the grains was lower at higher temperatures. The equilibrium moisture contents for security of storage, for long periods of time at water activity lower than 0.65 , were 12 $13 \%$. The effect of temperature on the parameters of the GAB model was analysed using the exponential Arrhenius equation. The isosteric heats of sorption were determined by applying the Clausius-Clapeyron equation as a function of humidity. The isosteric heat at 5\% moisture for grains of the Blanca de Juli variety was $3663 \mathrm{~kJ} / \mathrm{kg}$ and for the Pasankalla variety it was $3393 \mathrm{~kJ} / \mathrm{kg}$. The experimental data for isosteric heat as a function of humidity were satisfactorily modelled using three mathematical equations.
\end{abstract}

Keywords: Quinoa grains; moisture security; sorption isotherms; isosteric heat of sorption; mathematical models.

\section{Introduction}

Quinoa (Chenopodium quinoa Willdenow) is considered to be one of the most complete foods in the world; it is rich in nutrients, with a unique pattern of amino acids and a high content of polyunsaturated fatty acids and minerals (Bojanic, 2011). For this reason, the United Nations, through the auspices of the FAO, declared 2013 as the "International Year of Quinoa". Peru is one of the leading manufacturers and exporters of quinoa worldwide. In 2015, exports reached 142.2 million US dollars at an average value of U.S. $\$ 3.46 / \mathrm{kg}$ of quinoa. The USA is the main destination for these exports followed by the Unites Kingdom, Netherlands and Canada (AGRODATA, 2016).

In Peru, $80 \%$ of quinoa is grown in the highland region located at an altitude of 2500-4000 $\mathrm{m}$. The air at these altitudes contains saturation pressures, densities, moisture and temperatures that are lower than in the Amazonian and coastal regions. This causes the grains to naturally contain between 9 and $10 \%$ moisture at harvesting

\footnotetext{
* Corresponding author

E-mail: augusto.pumacahua@upeu.pe (A. Pumacahua-Ramos).
} 
time. However, the regions where quinoa is exported from are located at an altitude of less than $1500 \mathrm{~m}$. Under these conditions, if the quinoa grains are not properly stored they can absorb water up to levels that are not permitted by law, causing microbial deterioration and other adverse reactions.

Knowledge about the gain or loss of water in foods due to relative humidity is of vital importance in various stages of the consumption chain. This characteristic is specific to each type of food and can be checked experimentally. The water activity $\left(a_{w}\right)$ of a food is a characteristic that is temperature dependent, because above certain limits, chemical, enzymatic and microbiological reactions occur that are capable of causing it to deteriorate. The main cause of deterioration, apart from production, transportation, trade and consumption, is deterioration due to excess water absorbed from the environment. Sorption isotherms can be determined experimentally and can be adjusted to facilitate mathematical models that determine storage conditions and types of packaging. Various studies have been conducted to determine the sorption isotherms of dried foods and to adjust data to mathematical models (de Oliveira et al., 2014; Polachini et al., 2016; Rosa et al., 2015; Villa-Vélez et al., 2015).

Every aspect of the sorption or desorption of water involves energy. According to Aguerre and Viollaz (1989), this phenomenon occurs in the gas/solid interface of foods but it is the thermodynamic properties of water that regulate this phenomenon. The isosteric heat of sorption is a measure of the energy required for the evaporation or condensation of water from foods. This energy is variable in foods, due to the chemical bonding that the water molecules form with components such as fats, proteins, carbohydrates, etc. One way to understand more about this heat is through the study of sorption isotherms. There are have been several studies about isotherms and isosteric heats of sorption in grains such as quinoa, rice, orange peels, orange seeds, beans and soybeans (Aviara et al., 2004; Miranda et al., 2011; de Oliveira et al., 2014; Resende et al., 2006; Rosa et al., 2013; Villa-Vélez et al., 2015). Taking into consideration the importance of greater knowledge of the isotherms and energies involved in the process of water sorption, the objectives of this study were the following: to obtain the isothermic curves of two varieties of quinoa; to determine the models that best represented the experimental data; and to verify the sorption heat involved in the process.

\section{Materials and methods}

The experimental tests were conducted in the process laboratory at the Institute of Biosciences, Letters and Exact Sciences of the State University of São Paulo, SP, Brazil and the materials microscopy laboratory at the State University of Ponta Grossa, PR, Brazil. Quinoa grains of the Blanca de Juli and Pasankalla varieties, and of the seed type, from the 2009-10 crop, were obtained from the National Institute of Agrarian Investigation (INIA), Puno, Peru.

\subsection{Physical properties}

The grains were selected, placed in plastic bags, identified and stored in a cold room at $5{ }^{\circ} \mathrm{C}$. The initial moisture was determined by the standard oven method (105 ${ }^{\circ} \mathrm{C} / 24 \mathrm{~h}$ ) and the physical properties (geometric mean diameter, real density, apparent density, unit mass, porosity and sphericity) were determined according to the methodology of (Vilche et al., 2003). The surface of the grains was observed using a scanning electron microscope (SEM); the grains were previously coated in gold.

\subsection{Water sorption isotherms}

The saturated solutions of six salts $\left(\mathrm{MgCl}_{2}\right.$, $\mathrm{K}_{2} \mathrm{CO}_{3}, \mathrm{NaBr}, \mathrm{NaNO}_{2}, \mathrm{NaCl}$ and $\mathrm{KCl}$ ) were used to determine the sorption isotherms. The saturated solutions provided water activity $\left(a_{\mathrm{w}}\right)$ values from 0.278 to 0.823 for temperatures of $40,50,60$ and 
$70{ }^{\circ} \mathrm{C}$. Approximately two grams of quinoa were placed in each container and then placed in a BOD, model SP-500, incubator chamber. Constant mass was reached between 20 and 25 days and was quantified by the standard oven $\left(105^{\circ} \mathrm{C} / 24\right.$ h) method. The tests were performed in triplicate for both varieties.

\subsection{Modeling of sorption isotherms}

Six mathematical models used to fit experimental data are collected in Table 1 (Eqs. 1, 5 and 9). These were used to adjust the experimental data and to determine the model that gave the best fit for the experimental data.

Table 1

Mathematical models applied to the experimental sorption data for quinoa grains of two varieties

\begin{tabular}{|c|c|c|}
\hline Models & Equations & \\
\hline $\begin{array}{l}\text { GAB (Van den } \\
\text { Berg and Bruin, } \\
\text { 1981) }\end{array}$ & $X_{e}=\frac{X_{m} C k A_{w}}{\left(1-k A_{w}\right)\left(1-k A_{w}+C k A_{w}\right)}$ & (1) \\
\hline $\begin{array}{l}\text { Moisture } \\
\text { monolayer }\end{array}$ & $X_{m}=X_{0} \exp \left(\frac{\Delta X_{m}}{R T}\right)$ & (2) \\
\hline $\begin{array}{l}\text { Constant } \\
\text { monolayer }\end{array}$ & $C=C_{0} \exp \left(\frac{H_{m}-H_{n}}{R T}\right)$ & (3) \\
\hline $\begin{array}{l}\text { Constant } \\
\text { multilayer }\end{array}$ & $K=K_{0} \exp \left(\frac{\lambda-H_{n}}{R T}\right)$ & (4) \\
\hline $\begin{array}{l}\text { Peleg (Peleg, } \\
\text { 1993) }\end{array}$ & $X_{e}=k_{1} a_{w}^{n_{1}}+k_{2} a_{w}^{n_{2}}$ & (5) \\
\hline $\begin{array}{l}\text { Oswin (Oswin, } \\
1946 \text { ) }\end{array}$ & $X_{e}=A\left(\frac{a_{w}}{1-a_{w}}\right)^{B}$ & (6) \\
\hline $\begin{array}{l}\text { Henderson } \\
\text { (Henderson, } \\
\text { 1952) } \\
\end{array}$ & $X_{\theta}=\left(\frac{-\ln \left(1-a_{w}\right)}{A}\right)^{1 / B}$ & (7) \\
\hline $\begin{array}{l}\text { Halsey (Halsey, } \\
\text { 1948) }\end{array}$ & $X_{e}=\left(\frac{-A}{\ln a_{w}}\right)^{1 / B}$ & (8) \\
\hline $\begin{array}{l}\text { Smith (Smith, } \\
\text { 1947) }\end{array}$ & $X_{\theta}=A+B \ln \left(1-a_{w}\right)$ & (9) \\
\hline
\end{tabular}

In the equations shown in Table $1, X_{\mathrm{e}}$ is the equilibrium moisture content in $\%$ dry basis. In the GAB model the constants $X_{m}$, $C$ and $K$ are dependent on the temperature; $X_{m}$ represents the moisture of the molecular monolayer on the inner surface (Blahovec, 2004), $C$ is the constant related to the heat of sorption of the monolayer and $K$ is the heat of sorption of the multilayer compared to pure water (Moreira et al., 2008). In Table 1 (Eqs. 2, 3 and 4) the constants $X_{o}, C_{o}$ and $K_{o}$ are the parameters of the entropic character and
$\Delta H, H_{o}, H_{m}$ and $H_{L}(\mathrm{~kJ} / \mathrm{kg})$ are the heats of sorption of water in $X_{\mathrm{e}}$, in the monolayer, in the multilayer, and in pure water, respectively (Martín-Santos et al., 2012; Moreira et al., 2008; Polachini et al., 2016; Rosa et al., 2013; Villa-Vélez et al., 2015). In the Peleg model, $K_{1}, K_{2}, n_{1}$ and $n_{2}$ are constants and have the restrictions that $n_{1}<1$ and $n_{2}>1$. In the Oswin, Henderson, Halsey and Smith models, $A, B, C$ are constants and $\mathrm{T}$ is the absolute temperature. The adjustments to the models were made using SOLVER from the Excel $^{\odot}$ programme of Windows ${ }^{\circledR} 2010$.

\subsection{Determination of the isosteric heat of sorption}

The isosteric heat of sorption, $Q_{\mathrm{s}}$, (Eq. 10), or heat of sorption, is the energy required to remove water from a solid matrix. This corresponds to the enthalpy of the vaporisation of water from a food, which is always greater than pure water. In seeds, such as quinoa grains, water molecules are distributed in the intercellular and extracellular spaces in such a way that they are linked to molecules of starch, fat, protein and other components. $Q_{S}$ represents the sum of the net isosteric heat, $q_{S}$, and the enthalpy of vaporisation of pure water, $H_{L}$.

$Q_{S}=q_{s}+H_{L}$

The enthalpy of vaporisation or condensation of pure water can be calculated using Eq. (11):

$H_{L}=2501-2.361 T\left(R^{2}=0.998\right)$

The $q_{S}$ can be calculated by using the Clausius-Clapeyron graphical Eq. (12) on a given $X_{\mathrm{e}}$ (Martín-Santos et al., 2012; Miranda et al., 2011; Thys et al., 2010) and by the integrated method of Eq. (13) (Chen, 2006; Thys et al., 2010):

$\left(\ln a_{w}\right)_{X_{B}}=-\frac{q_{S}}{R T}+\frac{s_{d}}{R}$

$\mathrm{q}_{\mathrm{s}}=\mathrm{R}\left(\frac{\mathrm{T}_{1} \mathrm{~T}_{2}}{\mathrm{~T}_{2}-\mathrm{T}_{1}}\right) \ln \left(\frac{\mathrm{a}_{\mathrm{W} 2}}{\mathrm{a}_{\mathrm{W} 1}}\right)$

Where $R$ is the general gas constant $(0.462$ $\mathrm{kJ} / \mathrm{kg} \mathrm{K}$ ) and $\mathrm{T}$ is the absolute temperature in degrees Kelvin. Plotting $\ln a_{w}$ vs $1 / \mathrm{T}$ (Eq. 12) for different equilibrium moisture contents and adjusting to a straight, the slope $\left(q_{s} / R\right)$ is obtained. In Eq. (13), the water activities correspond to temperatures 
of $40\left(\mathrm{~T}_{1}\right)$ and $70{ }^{\circ} \mathrm{C}\left(\mathrm{T}_{2}\right)$. Both methods showed no significant differences in the calculated values (Mulet et al., 1999), which were obtained using Eq. (13).

The $\left(\mathrm{a}_{\mathrm{w}}\right)$ for each $X_{\mathrm{e}}$ were determined by the constants of the GAB model, $X_{m}, C$ and $K$, according to the methodology used by (Villa-Vélez et al., 2012). In order to obtain the expressions for predicting the $Q_{\mathrm{S}}$ of the quinoa grain, the following Eqs. (14 to 16) were used (Chen, 2006; Mulet et al., 1999; Tsami, 1991):

$$
\begin{aligned}
& Q_{s}=q_{0} \exp \left(-\frac{x_{\theta}}{x_{0}}\right)+H_{L} \\
& Q_{s}=q_{0} \exp \left(-K_{1} X_{e}\right)+H_{L} \\
& Q_{s}=q_{0} \exp \left(-K_{2} X_{e}\right) X_{e}^{K_{3}}+H_{L}
\end{aligned}
$$

Where $q_{o}$ is the heat of sorption of the monolayer, $X_{\mathrm{o}}$ is the initial moisture of the product; $K_{1}, K_{2}$ and $K_{3}$ are constants.

The moisture equilibriums and heats of sorption calculated by the models in relation to the experimental values were evaluated by the coefficient of determination, $\mathrm{R}^{2}$ and the mean absolute error (MA\%E) (Chen, 2006; Miranda et al., 2011; Silva et al., 2010; Tolaba et al., 2004), defined as:

$M A \% E=\frac{100}{N} \sum_{n=1}^{\infty} \frac{\left|x_{e}-x_{C}\right|}{x_{e}}$

\section{Results and discussion}

\subsection{Physical properties}

The moisture content ( $\%$ dry basis), geometric mean diameter $(\mathrm{mm})$, unit mass $(\mathrm{mg})$, real density $\left(\mathrm{kg} / \mathrm{m}^{3}\right)$, apparent density $\left(\mathrm{kg} / \mathrm{m}^{3}\right)$, porosity $(\%)$ and sphericity (\%) of the grains at the beginning of the tests were $11.81 \pm 0.07$ and $11.16 \% \pm 0.06 ; 1.66 \pm 0.04$ and 1.73 $\pm 0.15 \mathrm{~mm} ; 2.92 \pm 0.05$ and $3.55 \pm 0.15$; $1213.1 \pm 36.8$ and $1277.6 \pm 22.9 ; 661.7 \pm 2.9$ and $681.6 \pm 2.6 ; 45.45$ and $46.64 \% ; 85 \pm 7$ and $86 \pm 6$ for the Blanca de Juli quinoa and the Pasankalla quinoa, respectively. Similar diameters and densities were determined for Ecuadorian and Argentinian quinoa (Alvarado, 2012; Vilche et al., 2003).

Figure 1 shows a quinoa grain magnified by $30 x$ and Figure 2 shows a grain magnified by $270 x$. The grain is a seed type, untreated for the removal of saponin, which is a characteristic of commercial grains. It can be seen that the surface roughness is well organised, which contributes to the increase in the surface area for adsorption or desorption. According to Sukhorukov and Zhang (2013) this is a typical characteristic of seeds from the Chenopodioideae family.

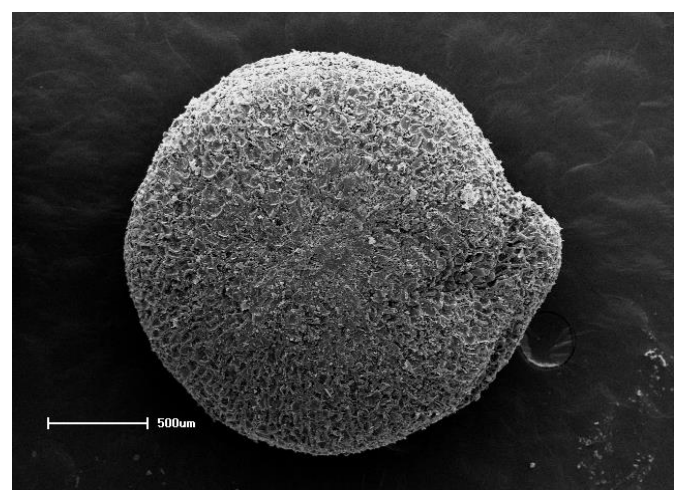

Figure 1. Scanning electron microphotographs of grain quinoa at 30x magnification.

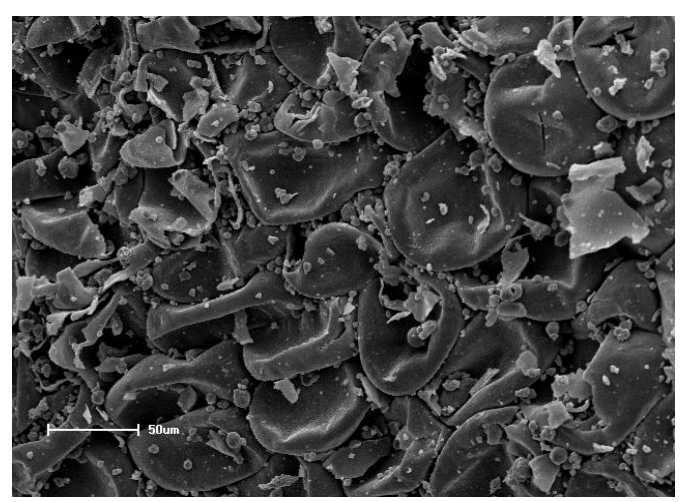

Figure 2. Scanning electron microphotographs of grain quinoa surface at 270x magnification.

\subsection{Water sorption isotherms}

The data for water activity and moisture equilibrium for the four temperatures are shown in Table 2. Figure 3 shows the effect of temperature on the isotherms of both varieties of quinoa. An inverse relationship between $X_{\mathrm{e}}$ and temperature was observed. Foods with water activity less than 0.65 can be stored for long periods without risk of mould growth. 
Table 2

Equilibrium moisture content $\left(X_{\mathrm{e}}, \%\right.$ d.b.) obtained by adsorption at different water activity and temperatures for quinoa grains of two varieties

\begin{tabular}{|c|c|c|c|c|c|c|c|c|}
\hline \multirow{3}{*}{ Salts } & \multicolumn{8}{|c|}{ Blanca de Juli } \\
\hline & \multicolumn{2}{|c|}{$40^{\circ} \mathrm{C}$} & \multicolumn{2}{|c|}{$50^{\circ} \mathrm{C}$} & \multicolumn{2}{|c|}{$60^{\circ} \mathrm{C}$} & \multicolumn{2}{|c|}{$70^{\circ} \mathrm{C}$} \\
\hline & $a_{w}$ & $\mathrm{X}_{\mathrm{eq}}$ & $a_{w}$ & $\mathrm{X}_{\mathrm{eq}}$ & $a_{w}$ & $X_{\text {eq }}$ & $a_{w}$ & $\mathrm{X}_{\mathrm{eq}}$ \\
\hline $\mathrm{MgCl}_{2}$ & 0.316 & 8.95 & 0.3054 & 7.27 & 0.2926 & 5.49 & 0.278 & 4.73 \\
\hline $\mathrm{K}_{2} \mathrm{CO}_{3}$ & 0.4 & 10.10 & 0.381 & 9.14 & 0.362 & 6.87 & 0.343 & 6.41 \\
\hline $\mathrm{NaBr}$ & 0.5317 & 12.19 & 0.5093 & 10.20 & 0.4966 & 8.55 & 0.497 & 8.26 \\
\hline $\mathrm{NaNO}_{2}$ & 0.615 & 12.85 & 0.599 & 10.79 & 0.59 & 9.73 & 0.587 & 8.95 \\
\hline $\mathrm{NaCl}$ & 0.7468 & 14.66 & 0.7443 & 14.08 & 0.745 & 12.66 & 0.751 & 11.85 \\
\hline \multirow[t]{2}{*}{$\mathrm{KCl}$} & 0.8232 & 17.03 & 0.812 & 15.74 & 0.8025 & 13.70 & 0.795 & 12.36 \\
\hline & \multicolumn{8}{|c|}{ Pasankalla } \\
\hline $\mathrm{MgCl}_{2}$ & 0.316 & 7.13 & 0.3054 & 6.35 & 0.2926 & 5.44 & 0.278 & 5.06 \\
\hline $\mathrm{K}_{2} \mathrm{CO}_{3}$ & 0.4 & 8.38 & 0.381 & 7.33 & 0.362 & 6.68 & 0.343 & 6.19 \\
\hline $\mathrm{NaBr}$ & 0.5317 & 9.88 & 0.5093 & 9.25 & 0.4966 & 8.32 & 0.497 & 8.04 \\
\hline $\mathrm{NaNO}_{2}$ & 0.615 & 11.46 & 0.599 & 10.13 & 0.59 & 9.19 & 0.587 & 9.07 \\
\hline $\mathrm{NaCl}$ & 0.7468 & 15.69 & 0.7443 & 14.46 & 0.745 & 12.88 & 0.751 & 12.62 \\
\hline $\mathrm{KCl}$ & 0.8232 & 18.51 & 0.812 & 17.24 & 0.8025 & 14.42 & 0.795 & 13.73 \\
\hline
\end{tabular}

In the present study, in terms of water activity, the quinoa grains that showed values of 0.615 reached moisture contents of 12.85 and $11.46 \%$ at $40{ }^{\circ} \mathrm{C}$ for the Blanca de Juli and Pasankalla varieties, respectively. Similar behaviour has been determined in grains of different varieties of quinoa (Alvarado, 2012; Miranda et al., 2011; Tolaba et al., 2004).
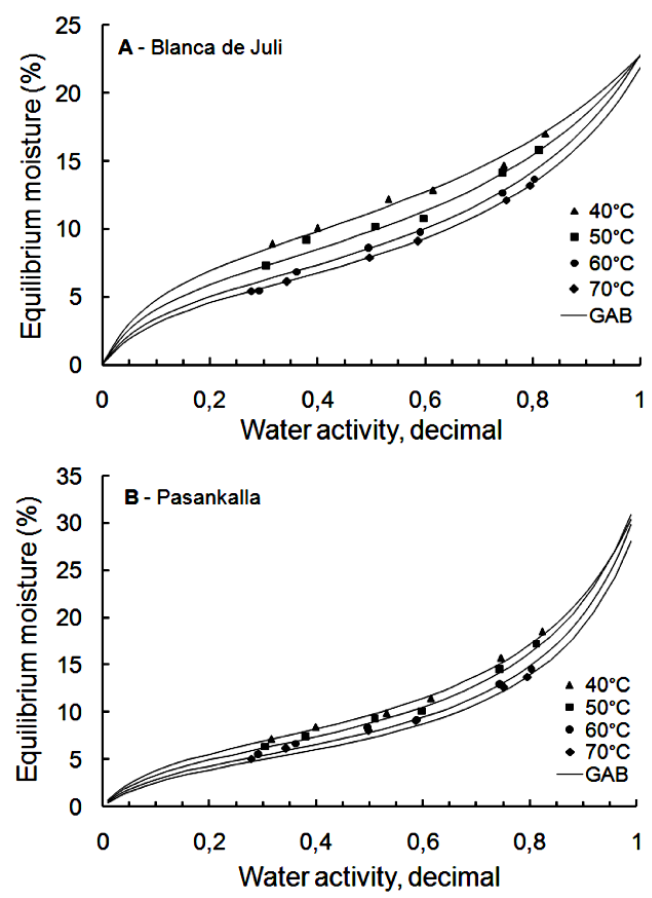

Figure 3. Experimental data of equilibrium moisture contents for quinoa grains of varieties Blanca de Juli (A) and Pasankalla (B). Lines correspond to the GAB model (Eq. 1).
The maximum experimental equilibrium moisture contents, with water activities from 0.80 to 0.82 at the four experimental temperatures, were $17.03-12.36 \%$ and $18.51-13.73 \%$ for the Blanca de Juli and Pasankalla varieties, respectively. The Pasankalla variety absorbed more water than the Blanca de Juli variety, with water activities greater than 0.8 at the four temperatures.

Table 3 shows the values of the regression parameters for the adjustments of data for $X_{\mathrm{e}}$ versus $a_{\mathrm{w}}$ in terms of the mathematical models for the two varieties of quinoa.

All the models had good fits, with $\mathrm{R}^{2}$ greater than 0.977 and $\mathrm{MA} \% \mathrm{E}$ less than $8.48 \%$. The mean $\mathrm{MA} \% \mathrm{E}$ for the four temperatures was less than $5.7 \%$. The constants of the GAB model $(X m, C$ and $K$ ) varied with temperature, confirming behaviour found by other authors (Blahovec, 2004; Moreira et al., 2008). According to Blahovec (2004), the constant $C$ decreases and $K$ increases with increasing temperature. This observation was confirmed in the present study. On the other hand, the constant $C$ was greater than 2.0, and the constant $K$ was less than 1.0, so the isotherms were classified as Type II (Brunauer et al., 1940). This behaviour has also been observed for several varieties of yellow corn and quinoa (Alvarado, 2012; Miranda et al., 2011; Samapundo et al., 2007; Tolaba et al., 2004). 
Table 3

Estimated values of coefficients models; determination coefficient $\left(\mathrm{R}^{2}\right)$ and mean relative error $(\mathrm{MR} \% \mathrm{E})$ for quinoa grains of two varieties

\begin{tabular}{|c|c|c|c|c|c|c|c|c|c|}
\hline \multirow[b]{2}{*}{ Model } & \multirow[b]{2}{*}{ Constant } & \multicolumn{4}{|c|}{ Blanca de Juli } & \multicolumn{4}{|c|}{ Pasankalla } \\
\hline & & $40^{\circ} \mathrm{C}$ & $50^{\circ} \mathrm{C}$ & $60^{\circ} \mathrm{C}$ & $70^{\circ} \mathrm{C}$ & $40^{\circ} \mathrm{C}$ & $50^{\circ} \mathrm{C}$ & $60^{\circ} \mathrm{C}$ & $70^{\circ} \mathrm{C}$ \\
\hline \multirow{5}{*}{ GAB } & $X m$ & 8.77 & 7.30 & 6.09 & 5.62 & 6.43 & 5.73 & 5.08 & 4.71 \\
\hline & $C$ & 15.39 & 14.45 & 13.60 & 12.50 & 13.68 & 12.83 & 11.55 & 10.65 \\
\hline & $K$ & 0.63 & 0.69 & 0.74 & 0.75 & 0.80 & 0.83 & 0.84 & 0.84 \\
\hline & $\mathrm{R}^{2}$ & 0.99 & 0.98 & 0.99 & 0.98 & 0.996 & 0.996 & 0.995 & 0.995 \\
\hline & MA\%E & 2.83 & 2.93 & 3.31 & 5.79 & 2.3 & 2.7 & 3.8 & 6.8 \\
\hline \multirow{4}{*}{ OSWIN } & $A$ & 11.26 & 10.09 & 8.50 & 8.03 & 9.81 & 9.07 & 8.34 & 8.01 \\
\hline & $B$ & 0.27 & 0.30 & 0.37 & 0.35 & 0.41 & 0.44 & 0.39 & 0.40 \\
\hline & $\mathrm{R}^{2}$ & 0.98 & 0.98 & 0.99 & 0.98 & 0.995 & 0.996 & 0.996 & 0.998 \\
\hline & MA\%E & 1.66 & 3.24 & 2.91 & 5.19 & 2.0 & 1.3 & 2.5 & 2.0 \\
\hline \multirow{4}{*}{ HENDERSON } & $K$ & 0.002 & 0.007 & 0.007 & 0.010 & 0.018 & 0.019 & 0.012 & 0.011 \\
\hline & $N$ & 2.35 & 1.97 & 2.16 & 2.02 & 1.58 & 1.60 & 1.86 & 1.90 \\
\hline & $\mathrm{R}^{2}$ & 0.988 & 0.977 & 0.998 & 0.988 & 0.984 & 0.982 & 0.990 & 0.994 \\
\hline & МА\%Е & 1.71 & 2.82 & 5.18 & 4.38 & 3.7 & 3.8 & 6.5 & 7.5 \\
\hline \multirow{6}{*}{ PELEG } & $K_{1}$ & 14.48 & 13.52 & 9.81 & 10.97 & 10.17 & 13.11 & 11.41 & 10.31 \\
\hline & $\mathrm{n}_{1}$ & 3.84 & 4.33 & 1.90 & 2.68 & 3.87 & 5.64 & 3.68 & 3.55 \\
\hline & $K_{2}$ & 7.81 & 8.83 & 7.71 & 4.96 & 19.08 & 18.44 & 10.42 & 10.33 \\
\hline & $\mathrm{n}_{2}$ & 0.42 & 0.51 & 0.59 & 0.54 & 0.34 & 0.61 & 0.49 & 0.52 \\
\hline & $\mathrm{R}^{2}$ & 0.980 & 0.982 & 0.996 & 0.988 & 0.998 & 0.997 & 0.995 & 0.998 \\
\hline & МА $\% \mathrm{E}$ & 1.66 & 2.89 & 1.46 & 4.24 & 1.2 & 1.1 & 2.4 & 1.8 \\
\hline \multirow{4}{*}{ SMITH } & $A$ & 7.20 & 5.48 & 4.04 & 4.12 & 3.87 & 3.23 & 2.35 & 3.45 \\
\hline & $B$ & 5.67 & 6.14 & 6.31 & 5.46 & 8.45 & 8.23 & 7.70 & 6.49 \\
\hline & $\mathrm{R}^{2}$ & 0.982 & 0.981 & 0.986 & 0.968 & 0.995 & 0.994 & 0.995 & 0.997 \\
\hline & МА $\% \mathrm{E}$ & 2.37 & 3.65 & 3.41 & 5.65 & 2.12 & 2.20 & 5.37 & 2.37 \\
\hline \multirow{4}{*}{ HALSEY } & $\bar{A}$ & 874.08 & 359.36 & 235.63 & 323.15 & 64.41 & 61.74 & 46.67 & 43.80 \\
\hline & $B$ & 2.97 & 2.70 & 2.68 & 2.65 & 2.00 & 2.00 & 2.00 & 2.00 \\
\hline & $\mathrm{R}^{2}$ & 0.981 & 0.981 & 0.983 & 0.965 & 0.996 & 0.997 & 0.992 & 0.993 \\
\hline & МA\%E & 2.41 & 3.77 & 8.12 & 8.48 & 2.43 & 5.75 & 3.68 & 3.85 \\
\hline
\end{tabular}

The GAB model is often used to determine energies related to adsorption sites in the monolayer and multilayer and the thermosdynamic properties of water in foods (Martín-Santos et al., 2012; Miranda et al., 2011; Moreira et al., 2008; Thys et al., 2010; Tolaba et al., 2004; Villa-Vélez et al., 2015). Figure 2 shows the adjustments to the GAB model for the experimental points of moisture equilibrium and the $a_{\mathrm{w}}$ of the two varieties of quinoa at the four tested temperatures.

The activation energy (Table 4), $\Delta H$, obtained for the moisture of the monolayer, $X_{m}$, represents the energy required to break or bind water molecules to the solid water system in this position (MartínSantos et al., 2012). The values for this energy were 943.25 and $523.38 \mathrm{~kJ} / \mathrm{kg}$ for the Blanca de Juli and Pasankalla varieties, respectively (Table 4). This shows that the Pasankalla grains absorbed water faster than the Blanca de Juli grains. The heats of sorption of the monolayer and multilayer of Blanca de Juli quinoa (2413 and 2074 $\mathrm{kJ} / \mathrm{kg}$, respectively) were lower than the heats of sorption for the Pasankalla quinoa (2705 and $2282 \mathrm{~kJ} / \mathrm{kg}$, respectively) (Table $4)$.

\section{Table 4}

Estimated values of coefficients models GAB; determination coefficient $\left(\mathrm{R}^{2}\right)$ and mean relative error $(\mathrm{MR} \% \mathrm{E})$ for quinoa grains of two varieties

\begin{tabular}{lccccccccc}
\hline Variety & $\begin{array}{c}\Delta H \\
\mathrm{~kJ} / \mathrm{kg}\end{array}$ & $\begin{array}{c}\mathrm{R}^{2} \\
-\end{array}$ & $\begin{array}{c}H_{o-} H_{m} \\
\mathrm{~kJ} / \mathrm{kg}\end{array}$ & $\begin{array}{c}\mathrm{R}^{2} \\
-\end{array}$ & $\begin{array}{c}H_{L-} H_{m} \\
\mathrm{~kJ} / \mathrm{kg}\end{array}$ & $\begin{array}{c}\mathrm{R}^{2} \\
-\end{array}$ & $H_{o}$ & $\begin{array}{c}H_{m} \\
\mathrm{~kJ} / \mathrm{kg}\end{array}$ & $H_{L}$ \\
\hline Blanca de Juli & 943.25 & 0.981 & 338.78 & 0.989 & 297.17 & 0.932 & 2413 & 2074 & 2371 \\
Pasankalla & 523.38 & 0.995 & 423.84 & 0.989 & 89.66 & 0.905 & 2705 & 2282 & 2371 \\
\hline
\end{tabular}


When these figures are compared to the heats of sorption of the monolayer of two varieties of Ecuadorian quinoa (between 2667 and $2946 \mathrm{~kJ} / \mathrm{kg}$ ) and the heats of sorption of the multilayer (2483 to 2544 $\mathrm{kJ} / \mathrm{kg}$ ) at temperatures of 20,25 and $30{ }^{\circ} \mathrm{C}$ (Alvarado, 2012), it can be seen that the energy value of the monolayer in the Ecuadorian quinoa was higher, due to the water being more strongly bound to the substrate at lower temperatures.

\subsection{Isosteric heat of sorption}

The dependency of $\mathrm{Q}_{s}$ with $X_{\mathrm{e}}$ for the two varieties of quinoa is shown in Figure 4.

The graph in Figure 4 shows that the grains of Pasankalla quinoa showed lower heats of sorption than the Blanca de Juli grains; they were in the range of $5-17 \%$ moisture. This demonstrates that the grains of Pasankalla quinoa absorbed and/or lost more water than the Blanca de Juli grains. When moisture levels were over $20 \%$, the sorption heats were similar for both varieties of quinoa; there was a tendency for similar values for the enthalpy of vaporisation of pure water $\left(H_{L}\right) ; 2371$ $\mathrm{kJ} / \mathrm{kg}$ at an average temperature of $55^{\circ} \mathrm{C}$. Thus, it was confirmed that the $Q_{\mathrm{s}}$ increased with decreasing moisture in the grains. Similar results were observed in the desorption isotherms obtained by using Eq. (14) (Miranda et al., 2011; Tolaba et al., 2004).

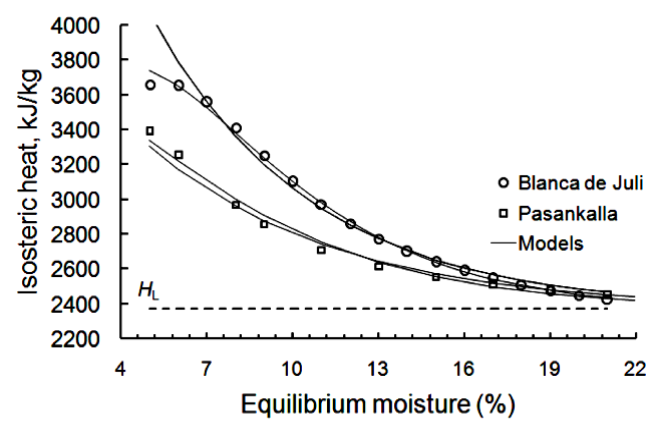

Figure 4. Effect of moisture content on the isosteric heat of sorption for quinoa grains of varieties Blanca de Juli and Pasankalla. Lines correspond to the models and heat of vaporization of water, $H_{\mathrm{L}}$.
At 5\% moisture levels, the Blanca de Juli variety had a sorption heat of $3663 \mathrm{~kJ} / \mathrm{kg}$ and the value for the Pasankalla variety was $3393 \mathrm{~kJ} / \mathrm{kg}$, confirming that the Pasankalla grains absorbed more water than the Blanca de Juli grains. Quinoa grains of the Real variety from Bolivia needed between $4000-5000 \mathrm{~kJ} / \mathrm{kg}$ of energy for moisture between $2-5 \%$ at temperatures of 20,30 and $40{ }^{\circ} \mathrm{C}$ (Tolaba et al., 2004). Quinoa grains from Chile showed values of $3400-3880 \mathrm{~kJ} / \mathrm{kg}$ for moisture levels below $4 \%$ at temperatures of 20, 40 and $60{ }^{\circ} \mathrm{C}$ (Miranda et al., 2011). Two Ecuadorian varieties of quinoa had values of between $3600-3900 \mathrm{~kJ} / \mathrm{kg}$ at $6 \%$ moisture and temperatures of 20,25 and 30 ${ }^{\circ} \mathrm{C}$ (Alvarado, 2012).

Table 5 shows the constants of the adjusment models for the experimental data for sorption heat. The three equations represented the experimental data very well. However, Eq. (17), with three parameters, showed a better $\mathrm{R}^{2}$ and a MA\%E of 0.997 and 0.991 ; and 0.338 and $1.115 \%$ for the Blanca de Juli and Pasankalla varities, respectively.

\section{Table 5}

Estimated values of coefficients models Eqs. (14 to 16) for determination isosteric heats of sorption

\begin{tabular}{lccc}
\hline Model & Constant & $\begin{array}{c}\text { Blanca de } \\
\text { Juli }\end{array}$ & Pasankalla \\
\hline & $q_{o}(\mathrm{~kJ} / \mathrm{kg})$ & 4192.200 & 2000.647 \\
Tsami & Xo $\%$ bs $)$ & 5.555 & 6.558 \\
(Eq. 14) & $\mathrm{R}^{2}$ & 0.959 & 0.977 \\
& $\mathrm{MA} \% \mathrm{E}$ & 1.396 & 1.054 \\
\hline & $K_{1}(\mathrm{~kJ} / \mathrm{kg})$ & 4167.860 & 2001.887 \\
Tsami & $K_{2}$ & 0.180 & 0.153 \\
(Eq. 15) & $\mathrm{R}^{2}$ & 0.959 & 0.977 \\
& $\mathrm{MA} \% \mathrm{E}$ & 1.399 & 1.055 \\
\hline & $K_{1}(\mathrm{~kJ} / \mathrm{kg})$ & 761.066 & 1310.405 \\
Mulet & $K_{2}$ & 0.309 & 0.220 \\
(Eq. 16) & $K_{3}$ & 1.326 & 0.495 \\
& $\mathrm{R}^{2}$ & 0.997 & 0.991 \\
& $\mathrm{MA} \% \mathrm{E}$ & 0.338 & 1.115 \\
\hline
\end{tabular}

\section{Conclusions}

Sorption curves were determined for two quinoa grain varieties at temperatures of 40 $-70{ }^{\circ} \mathrm{C}$ and water activity from $0.28-0.82$. 
The moisture safety values for long storage periods were approximately $12-13 \%$ for both varieties. At high relative humidities $\left(a_{\mathrm{w}}>0.74\right)$, the Pasankalla variety had a higher equilibrium moisture content than the Blanca de Juli variety. Of the six mathematical models that were tested, five models showed a MA\%E of less than $3.9 \%$; the most successful model was Peleg. The sigmoid type isotherms were classified as type II. The moisture contents for safe storage using the $X_{\mathrm{m}}$ constant in the GAB model were $8.77-5.62 \%$, and $6.43-4.71 \%$ for the Blanca de Juli and Pasankalla varieties, respectively at the studied temperature range. The energy required for water absorption (activation energy), the heats of sorption of the monolayer and multilayer, and the isosteric heat, were higher for the Blanca de Juli variety compared to the Pasankalla variety. The Pasankalla variety tended to gain water faster than the grains of the Blanca de Juli variety. The three presented models can be used to determine the isosteric heat as a function of grain moisture.

\section{Acknowledgements}

The authors acknowledge the University Peruana Unión - Juliaca (UPeU-J), the Institute of Biosciences, Letters and Exact Sciences of the State University of São Paulo, SP, Brazil and the State University of Ponta Grossa, PR for financial support.

\section{References}

AGRODATA. 2016. Exportaciones de quinua peruana. Available in: http://www.agrodataperu.com/category/quinuaexportacion

Aguerre, R.J.; Viollaz, P.E. 1989. Swelling and Pore Structure in Starchy Materials. Journal of Food Engineering 9: 71-80.

Alvarado, J. de D. 2012. Propiedades termodinámicas relacionadas con el agua constitutiva de alimentos. (Grafitext, Ed.) (1st ed.). Ambato, Ecuador. Retrieved from http://fcial.uta.edu.ec/images/stories/docs/libros/jdda_p trceacda.pdf

Aviara, N.A.; Ajibola, O.O.; Oni, S.A. 2004. Sorption Equilibrium and Thermodynamic Characteristics of Soya Bean. Biosystems Engineering 87: 179-190.

Blahovec, J. 2004. Sorption isotherms in materials of biological origin mathematical and physical approach. Journal of Food Engineering 65(4): 489-495.
Bojanic, A. 2011. La quinua: Cultivo milenario para contribuir a la seguridad alimentaria mundial. Available in:

http://www.fao.org/fileadmin/templates/aiq2013/res/es /cultivo_quinua_es.pdf

Brunauer, S.; Deming, L. S.; Deming, W. E.; Teller, E. 1940. On a theory of the van der Waals adsorption of gases. Journal of the American Chemical Society 62: 1723-1732.

Chen, C. 2006. Obtaining the isosteric sorption heat directly by sorption isotherm equations. Journal of Food Engineering 74(2): 178-185.

de Oliveira, D.E.C; Resende, O.; Campos, R.C.; Donadon, J. R. 2014. Obtenção e modelagem das isotermas de dessorção e do calor isostérico para sementes de arroz em casca. Científica 42(3): 203-210.

Halsey, G. 1948. Physical adsorptionon nonuniformsurfaces. Jornal Chemical Physical 16: 931937.

Henderson, S. M. 1952. A basic concept of equilibrium moisture. Agricultural Engineering 33: 29-32.

Martín-Santos, J.; Vioque, M.; Gómez, R. 2012. Thermodynamic properties of moisture adsorption of whole wheat flour. Calculation of net isosteric heat. International Journal of Food Science \& Technology 47(7): 1487-1495.

Miranda, M.; Vega-Gálvez, A.; Sanders, M.; López, J.; Lemus-Mondaca, R.; Martínez, E.; Scala, K. 2011. Modelling the Water Sorption Isotherms of Quinoa Seeds (Chenopodium quinoa Willd.) and Determination of Sorption Heats. Food and Bioprocess Technology 5(5): 1686-1693.

Moreira, R.; Chenlo, F.; Torres, M.D.; Vallejo, N. 2008. Thermodynamic analysis of experimental sorption isotherms of loquat and quince fruits. Journal of Food Engineering 88(4): 514-521.

Mulet, A.; Sanjuán, R.; Bon, J. 1999. Sorption Isosteric Heat Determination by Thermal Analysis and Sorption Isotherms. Journal of Food Science 64(1): 64-68.

Oswin, C.R. 1946. The kinetics of package life III. The isotherm. Journal of Chemical Industry 65: 419-421.

Peleg, M. 1993. Assessment of a semi-empirical four parameter general model for sigmoid moisture sorption isotherms. Journal of Food Process Engineering 16: 21-37.

Polachini, T.C.; Betiol, L.F.L.; Lopes-Filho, J.F.; TelisRomero, J. 2016. Water adsorption isotherms and thermodynamic properties of cassava bagasse. Thermochimica Acta 632: 79-85.

Resende, O.; Corrêa, P. C.; Goneli, L.A.D.; Ribeiro, D.M. 2006. Isotermas e Calor Isostérico de Sorção do Feijão. Ciência Tecnologia Alimentaria 26(3): 626631.

Rosa, D.P.; Luna-solano, G.; Polachini, T.C.; TelisRomero, J. 2015. Modelagem matemática da cinética de secagem de semente de laranja. Ciência Agrotecnologia Lavras 39(3): 291-300.

Rosa, D.P.; Villa-vélez, H.A.; Telis-Romero, J. 2013. Study of the enthalpy-entropy mechanism from water sorption of orange seeds (C. sinensis cv. Brazilian) for the use of agro-industrial residues as a possible source of vegetable oil production. Ciência E Tecnologia de Alimentos 33: 95-101.

Samapundo, S.; Devlieghere, F.; Meulenaer, B. De; Atukwase, A.; Lamboni, Y.; Debevere, J. M. 2007. Sorption isotherms and isosteric heats of sorption of whole yellow dent corn. Journal of Food Engineering 79: $168-175$.

Silva, S.A.; de Almeida, C.F.; Alves, N.M.C.; Melo, D.S.C.; Gomes, J.P. 2010. Hygroscopic and thermos- 
dynamic features of dehydrated coriander. Ciência Agronômica 41(2): 237-244.

Smith, S.E. 1947. The sorption of water vapour by high polymers. Journal of the American Chemical Society 69: 646.

Sukhorukov, A.P.; Zhang, M. 2013. Fruit and seed anatomy of Chenopodium and related genera (Chenopodioideae, Chenopodiaceae/ Amaranthaceae): Implications for evolution and taxonomy. Plos One 8(4): $1-18$

Thys, R.C.S.; Noreña, C.P.Z.; Marczak, L.D.F.; Aires, A.G.; Cladera-Olivera, F. 2010. Adsorption isotherms of pinhão (Araucaria angustifolia seeds) starch and thermodynamic analysis. Journal of Food Engineering 100(3): 468-473.

Tolaba, M.P.; Peltzer, M.; Enriquez, N.; Lucía-Pollio, M. 2004. Grain sorption equilibria of quinoa grains. Journal of Food Engineering 61(3): 365-371.
Tsami, E. 1991. Heat of sorption of water in dried fruits. International Journal of Food Science and Technology 25(3): 350-359.

Van den Berg, C.; Bruin, S. 1981. Water activity and its estimation in food systems: theoretical aspects. In Water Activity: Influences on Food Quality (pp. 161). New York: Academic Press.

Vilche, C.; Gely, M.; Santalla, E. 2003. Physical properties of quinoa seeds. Biosystems Engineering 86(1): 5965.

Villa-Vélez, H.A.; de Souza, S.J.F.; Pumacahua-Ramos, A.; Polachini, T.; Telis-Romero, J. 2015. Thermodynamic properties of water adsorption from orange peels. Journal of Bioenergy and Food Science 2(2): $72-81$.

Villa-Vélez, H.; Váquiro, H.; Bon, J.; Telis-Romero, J. 2012. Modelling Thermodynamic Properties of Banana Waste by Analytical Derivation of Desorption Isotherms. International Journal of Food Engineering 8(1): 1-19. 